\title{
Prevalence of Eimeria species of the domestic goats Capra hircus Linnaeus, 1758 in Al-Baha area, Saudi Arabia
}

\author{
Mohamed Moussa Ibrahim ${ }^{1,2}$
}

1- Zoology Department, Faculty of Science, Suez Canal University, Ismailia, Egypt

2- Science Department, Faculty of Education, Al-Baha University, Al-Baha, Saudi Arabia

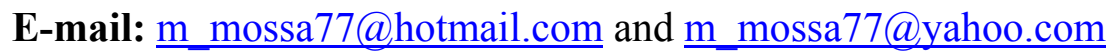

\begin{abstract}
This work aimed to identify Eimeria species of goats and to investigate the factors that might potentially influence their prevalence and parasite load. This study was conducted in Al-Baha area, south-west Saudi Arabia from September 2011 to June 2012. Out of 336 faecal samples examined, $180(53.57 \%)$ were positive for Eimeria oocysts. The prevalence of Eimeria ranged from $39.64 \%$ to $61.40 \%$ in different localities. Nine different Eimeria species were identified from faecal samples of goats. Eimeria species were: Eimeria arloingi (35.71\%), E. alijevi (26.19\%), E. hirci (25.29\%), E. ninakohlyakimovae (16.36\%), E. christenseni (14.59\%), E. caprina (11.31\%), E. jolchijevi (9.52\%), E. caprovina (5.59\%) and E. apsheronica (3.27\%). E. arloingi (35.71\%), E. alijevi $(26.19 \%)$ and E. hirci $(25.29 \%)$ were the most prevalent species and E. apsheronica $(3.27 \%)$ was the least prevalent one. The main factors affecting prevalence and parasite load of Eimeria species were host age, locality and season. Significant negative correlations were found between host age and both prevalence and OPG number. Multiple-species infections were detected in $89.44 \%$ of positive goats which carried two to five species. In conclusion, the prevalence of coccidiosis is relatively low compared to other studies. Moreover, no signs of clinical coccidiosis were found in this study. We need further research to study the interaction between multiple-species infections in coccidiosis and parasite load in natural host-parasite systems.
\end{abstract}

Keywords: Eimeria, oocysts, goats, host age, season, Saudi Arabia.

\section{INTRODUCTION}

Domesticated small ruminants, especially goats, constitute an important source of animal protein to most inhabitants in Saudi Arabia. A lot of socio-economic importance is therefore attached to ownership of these animals. However, the productivity of goats is constrained by parasitic infections (Dhar et al., 1982; Ibrahim et al., 2008). Coccidiosis is a worldwide distributed disease and one of the most economically important infections that threatening goats production (Alyousif et al., 1992; Gül, 2007; Wang et al., 2010; Cavalcante et al., 2012). Coccidiosis is a parasitic disease caused by intracellular protozoa called Eimeria. Eimeria can invade and destroy intestinal cells of the hosts, causing anaemia, electrolyte loss and poor absorption of nutrients. The most common sign of infection is diarrhoea, and affected goats can show a rough hair coat, poor weight gain and weakness (Wang et al., 2010).

Thirteen Eimeria species have been reported from the goats (Pellérdy, 1974; Levine, 1985; Norton, 1986; Wang et al., 2010). In Saudi Arabia, ten Eimeria species have been found in goats, namely E. arloingi, E. alijevi, E. ninakohlyakimovae, E. 
hirei, E. christenseni, E. caprina, E. apsheronica, E. caprovina, E. punctate and E. jolehijevi (Alyousif et al., 1992).

Alyousif et al. (1992) showed that infection of goats with Eimeria species is common in the central region of Saudi Arabia. There are no studies of prevalence of Eimeria infection in goats in Al-Baha area, which has unique climatic and geographic conditions different from other areas of Saudi Arabia. This area has very cold and dry winter season, but has a warm and rainy temperate climate during the spring and summer seasons in Al-Baha locality. Therefore, the objective of the present study was to investigate the factors affecting in prevalence and parasite load of Eimeria species of goats. The results obtained would be quite useful to devise appropriate and effective control strategies and prophylactic programs for coccidiosis of goat unique to this climatic zone and other parts of the world with similar climatic and husbandry production systems.

\section{MATERIAL AND METHODS}

\section{The study area}

The study was conducted in Al-Baha area, south-west Saudi Arabia $\left(20^{\circ} \mathrm{N}, 41-\right.$ $42^{\circ} \mathrm{E}$ ) from September 2011 to June 2012 . The study area is mainly hilly, with small areas of either mountainous or flat land and extends from 500 to $2500 \mathrm{~m}$ a.s.l. The climate in Al-Baha has two extremes. Mild winters and hot summers, with an average annual rainfall between 100 and $250 \mathrm{~mm}$, prevail in the lowlands; cold winters and mild summers, with an average annual rainfall between 229 and $581 \mathrm{~mm}$, prevail in the highlands (Ibrahim et al., 2008).

\section{Sample collection}

A total of 336 goats from three localities in Al-Baha area were randomly chosen from each sheepfold. Faecal samples of approximately 3-5 g were collected directly from the rectum using examination gloves. All samples were placed into plastic bags and were classified into three age categories: < 6-months old (90 goats), 6-12-months old (121 goats) and >12-months old (125 goats) and two seasons (dry: September 2011-January 2012 and wet season: February 2012-June 2012). The structure of the sampled host population of goats according to season, locality, sex and age categories was shown in Table (1). The collected samples were stored at $4^{\circ} \mathrm{C}$ until being examined.

Table 1: The structure of the sampled host population of goats.

\begin{tabular}{ccc}
\hline Factors considered & No. of goats examined \\
\hline \multirow{2}{*}{ Season } & Dry season (September 2011-January 2012) & 155 \\
& Wet season (February 2012-June 2012) & 181 \\
\hline \multirow{2}{*}{ Location } & Al-Baha & 111 \\
& Al-Aqiq & 111 \\
\multirow{2}{*}{ Sex } & Al-Mikhwah & 114 \\
\hline \multirow{2}{*}{ Age categories } & Male & 183 \\
& Female & 153 \\
\hline & $<6$ months old & 90 \\
& $6-12$ months old & 121 \\
& $>12$ months old & 125 \\
\hline
\end{tabular}

\section{Sample processing and recovery of Eimerian oocysts}

Faecal samples was examined for the presence or absence of eimerian oocysts by a flotation technique using saturated saline. Oocysts per gram of faeces (OPG) were quantified using a modification of the McMaster technique (MAFF, 1986). 
Oocysts in two chambers of the McMaster slide were counted and the sum number of oocysts in both chambers was multiplied by the dilution factor (100) to obtain an estimation of the number of OPG of each faecal sample. Each faecal sample was examined three times using the same method (Wang et al., 2010, Cavalcante et al., 2012). The results are expressed as the mean value of the three independent examinations.

\section{Eimerian species identification}

After examination, positive samples were filtered through sieves covered with folded gauze and centrifuged at $250 \times \mathrm{g}$ for $10 \mathrm{~min}$. Filtered material was placed into Petri dishes with $2.5 \%$ potassium dichromate solution $\left(\mathrm{K}_{2} \mathrm{Cr}_{2} \mathrm{O}_{7}\right)$ for sporulation at laboratory temperature. After sporulation, sporulated oocysts were recovered by centrifugation in saturated saline solution at $250 \times \mathrm{g}$ for $5 \mathrm{~min}$ followed by washing with distilled water. Concentration of sporulated oocysts was performed by centrifugation at $250 \times \mathrm{g}$ for $10 \mathrm{~min}$, stored in potassium dichromate solution at $4^{\circ} \mathrm{C}$ for subsequent study. The oocysts were identified based on their morphological characteristics (size, shape, colour, form index, presence or absence of micropyle and its cap, presence or absence of residual, polar and stieda bodies) of the oocysts and sporocysts (Pellérdy, 1974; Levine, 1985; Soulsby, 1986; Wang et al., 2010; Cavalcante et al., 2012). To ensure that species identification is valid, when possible, at least 50 sporulated oocysts from each species were observed and measured (Wang et al., 2010, Cavalcante et al., 2012).

\section{Data analysis}

Prevalence was calculated according to Bush et al. (1997). Differences in prevalence of Eimeria among different age categories of goats, as well as among different localities were evaluated using a Chi square test. Comparisons of OPG numbers according to sex and season were tested using Mann-Whitney test (U-test) while according age categories and locality were tested by Kruskal Wallis. Correlations between host age and both prevalence and OPG number were examined by using the non-parametric, Spearman's rank correlation coefficients $\left(r_{s}\right)$. All the statistical tests were performed by using the software packages SPSS 17.0 (USA) and a value of $\mathrm{P}<0.05$ was considered significant.

\section{RESULTS}

Out of 336 faecal samples examined, 180 (53.57\%) were positive for Eimeria oocysts. The prevalence of Eimeria oocysts in the three localities of Al-Baha area ranged from $39.64 \%$ to $61.40 \%$. Statistically significant differences were found in prevalence $\left(\mathrm{X}^{2}=12.98, d f=2, P=0.002\right)$ and OPG $\left(\mathrm{X}^{2}=10.69, d f=2, P=0.005\right)$ among different localities of Al-Baha area. The highest prevalence $(61.40 \%)$ and OPG $(182.56 \pm 35.96)$ were observed in goats in Al-Mikhwah locality. The lowest prevalence (39.64\%) was observed in goats in Al-Baha locality (Table 2). Nine different Eimeria species were identified from faecal samples of goats collected from Al-Baha area.

Table 2: Prevalence and parasite load of Eimeria oocysts in goats in different localities of Al-Baha area.

\begin{tabular}{lccccc}
\hline Locality & $\begin{array}{c}\text { Examined } \\
\text { number }\end{array}$ & $\begin{array}{c}\text { Infected } \\
\text { number }\end{array}$ & $\begin{array}{c}\text { Prevalence } \\
(\mathbf{\%})\end{array}$ & $\begin{array}{c}\text { Significance among } \\
\text { location }\end{array}$ & $\begin{array}{c}\text { Mean no. of oocysts per } \\
\text { gram of faeces (range) }\end{array}$ \\
\hline Al-Baha & 111 & 44 & 39.64 & $\mathrm{X}^{2}=12.98, d f=2$, & $102.80 \pm 23.95(0-1209)$ \\
Al-Aqiq & 111 & 66 & 59.46 & $P=0.002$ & $180 \pm 34.45(0-1809)$ \\
Al-Mikhwah & 114 & 70 & 61.40 & & $182.56 \pm 35.96(0-1875)$ \\
\hline
\end{tabular}


The prevalence of these Eimeria species was: Eimeria arloingi (Marotel, 1905) Martin, 1909 (35.71\%), E. alijevi Musaev, 1970 (26.19\%), E. hirci Chevalier, 1966 (25.29\%), E. ninakohlyakimovae Yakimoff \& Rastegaieff, 1930 (16.36\%), E. christenseni Levine, Ivens \& Fritz, 1962 (14.59\%), E. caprina Lima, 1979 (11.31\%), E. jolchijevi Musaev, 1970 (9.52\%), E. caprovina Lima, 1980 (5.59\%) and E. apsheronica Musaev, 1970 (3.27\%). E. arloingi (35.71\%), E. alijevi (26.19\%) and E. hirci $(25.29 \%)$ were the most prevalent species and E. apsheronica $(3.27 \%)$ was the least prevalent one (Table 3).

Table 3: Prevalence of Eimeria species in goats.

\begin{tabular}{lcc}
\multicolumn{1}{c}{ Eimeria species } & Number of infected goats & Prevalence (\%) \\
\hline Eimeria arloingi & 120 & 35.71 \\
E. alijevi & 88 & 26.19 \\
E. hirci & 85 & 25.29 \\
E. ninakohlyakimovae & 55 & 16.36 \\
E. christenseni & 49 & 14.59 \\
E. caprina & 38 & 11.31 \\
E. jolchijevi & 32 & 9.52 \\
E. caprovina & 20 & 5.59 \\
E. apsheronica & 11 & 3.27 \\
\hline
\end{tabular}

The prevalence of Eimeria oocysts in male was higher $(55.19 \%)$ than that in female $(51.63 \%)$. Also, the OPG number was higher in male $(157.66 \pm 26.19)$ when compared to female $(152.62 \pm 26.04)$. However, there were no statistically significant difference in prevalence $(\mathrm{X} 2=0.42, \mathrm{df}=1, \mathrm{P}=0.52)$ and $\mathrm{OPG}(U=13653 ; P=0.68)$ between male and female (Table 4).

Table 4: Prevalence and parasite load of Eimeria oocysts per host sex of goats.

\begin{tabular}{cccccc}
\hline Host sex & $\begin{array}{c}\text { Examined } \\
\text { number }\end{array}$ & $\begin{array}{c}\text { Infected } \\
\text { number }\end{array}$ & Prevalence $(\%)$ & $\begin{array}{c}\text { Significance } \\
\text { between host } \\
\text { sex prevalence }\end{array}$ & $\begin{array}{c}\text { Mean no. of oocysts per } \\
\text { gram of faeces (range) }\end{array}$ \\
\hline Male & 183 & 101 & 55.19 & & $157.66 \pm 26.16(0-1875)$ \\
Female & 153 & 79 & 51.63 & $\mathrm{X}^{2}=0.42, d f=1$, & $152.62 \pm 26.04(0-1709)$ \\
$P=0.52$ & & $155.37 \pm 18.52(0-1875)$ \\
\hline Total & 336 & 180 & 53.57 & &
\end{tabular}

The prevalences of Eimeria oocysts in age categories were $65.56 \%$ (59/90), $54.45 \%(66 / 121)$, and 44\% (55/125) in <6-months old, 6-12-months old and $>12$ months old respectively. The highest prevalence $(65.56 \%)$ was recorded in the youngest age category $(<6$-months old) and the lowest one $(44 \%)$ was observed in the oldest age category ( $>12$-months old). Moreover, OPG number was higher $(351.13 \pm 57.54)$ in $<6$-months when compared to other age categories (Table 5).

Table 5: Prevalence and parasite load of Eimeria oocysts in different age categories of goats.

\begin{tabular}{lccccc}
\hline Age categories & $\begin{array}{c}\text { Examined } \\
\text { number }\end{array}$ & $\begin{array}{c}\text { Infected } \\
\text { number }\end{array}$ & $\begin{array}{c}\text { Prevalence } \\
\mathbf{( \% )}\end{array}$ & $\begin{array}{c}\text { Significance } \\
\text { among age } \\
\text { categories } \\
\text { prevalence }\end{array}$ & $\begin{array}{c}\text { Mean no. of oocysts per } \\
\text { gram of faeces (range) }\end{array}$ \\
\hline <6 months old & 90 & 59 & 65.56 & & \\
6-12 months old & 121 & 66 & 54.45 & $\begin{array}{c}X^{2}=9.81, d f=2, \\
P=0.007\end{array}$ & $104.42 \pm 18.87(0-1123)$ \\
& 125 & 55 & 44 & & $63.72 \pm 11.89(0-619)$ \\
\hline Total & 336 & 180 & 53.57 & & $155.37 \pm 18.52(0-1875)$ \\
\hline
\end{tabular}


Significant difference was found in prevalence $\left(X^{2}=9.81, d f=2, P=0.007\right)$ and OPG number $\left(X^{2}=18.41, d f=2, P<0.001\right)$ among different age categories (Table 5). Significant negative correlation were found between host age and both prevalence $\left(r_{s}=0.17, \mathrm{P}=0.002\right)$ and $\mathrm{OPG}$ number $\left(r_{s}=0.23, \mathrm{P}<0.001\right)$.

There was seasonal difference in prevalence of Eimeria oocysts in goats. The prevalence of coccidial oocysts was significantly higher $(60.22 \%)$ in wet season than that in dry season $(45.81 \%)\left(X^{2}=9.81, d f=1, P=0.008\right)$. OPG numbers were significantly higher $(173.15 \pm 27.56)$ when compared to that in dry season (Table 6; $U=12366.5, P=0.049$ ).

Table 6: Prevalence and parasite load of Eimeria oocysts in different seasons in Al-Baha area, Saudi Arabia.

\begin{tabular}{lccccc}
\hline Season & $\begin{array}{c}\text { Examined } \\
\text { number }\end{array}$ & $\begin{array}{c}\text { Infected } \\
\text { number }\end{array}$ & $\begin{array}{c}\text { Prevalence } \\
(\%)\end{array}$ & $\begin{array}{c}\text { Significance among age } \\
\text { categories prevalence }\end{array}$ & $\begin{array}{c}\text { Mean no. of oocysts } \\
\text { per gram of faeces } \\
\text { (range) }\end{array}$ \\
\hline Dry season & 155 & 71 & 45.81 & & $134.60 \pm 24.00(0-1623)$ \\
Wet season & 181 & 109 & 60.22 & $X^{2}=6.95, d f=1, P=0.008$ & $173.15 \pm 27.56(0-1875)$ \\
\hline
\end{tabular}

Multiple-species infections (simultaneous infections with multiple parasite species in an individual host) of more than one Eimeria species were commonly present in all age categories. Multiple-species infections were detected in $89.44 \%$ $(161 / 180)$ of positive goats which carried two to five species; $67.77 \%(122 / 180)$ of positive goats had two to three species. Infections with 4 and 5 species were less common $(21.66 \%$; 39/180) (Table 7).

Table 7: Percentage of single and multiple-species infections of different Eimeria species in goats in Al-Baha, Saudi Arabia.

\begin{tabular}{lllllll}
\hline $\begin{array}{l}\text { The number of Eimeria species in } \\
\text { examined samples }\end{array}$ & $\mathbf{0}$ & $\mathbf{1}$ & $\mathbf{2}$ & $\mathbf{3}$ & $\mathbf{4}$ & $\mathbf{5}$ \\
\hline $\begin{array}{l}\text { Infected goats } \\
\text { Percentage (\%) }\end{array}$ & 157 & 18 & 49 & 73 & 27 & 12 \\
\hline
\end{tabular}

\section{DISCUSSION}

In the present study, the prevalence of Eimeria species infection was $53.57 \%$ in goats in Al-Baha area, south-west Saudi Arabia. This finding is lower than those reported in central region of Saudi Arabia (Alyousif et al., 1992), Turkey (Gül, 2007), northeastern China (Wang et al., 2010), Barazil (Cavalcante et al., 2012), which revealed a prevalence of $90.3 \%, 82.55 \%, 90.9 \%, 91.2 \%$ in goats respectively. These differences in prevalence may be due to various sanitation efforts in the management programs attempted by goat producers to control coccidiosis or due to differences in ecological condition.

Thirteen Eimeria species known to infect goats (Pellérdy, 1974; Levine 1985; Norton, 1986; Wang et al., 2010), ten of them were previously reported in Saudi Arabia, namely E. arloingi, E. alijevi, E. ninakohlyakimovae, E. hirei, E. christenseni, E. caprina, E. apsheronica, E. caprovina, E. punctate and E. jolehijevi (Alyousif et al., 1992). But we found only nine species in goats including all species that found by Alyousif et al. (1992) except one species, namely E. punctate. The reported species in this study is similar to those recorded in Poland by Balicka-Ramisz (1999). E. arloingi (35.71\%), E. alijevi (26.19\%) and E. hirci (25.29\%) were more frequent. This result is similar to those reported by Alyousif et al. (1992), Harper and Penzhorn (1999), Gül (2007), Wang et al. (2010) and Cavalcante et al. (2012). The present results 
demonstrated that multiple-species infections with two or three Eimeria species were more commonly seen than infection with a single Eimeria species. This finding is consistent with findings of other researchers (Alyousif et al., 1992; Wang et al. 2010; Cavalcante et al. 2012).

The prevalence and OPG of Eimeria oocysts in lower age category (kids) $(89.5 \%)$ were significantly higher than that in adult goats $(87.5 \%)$. Moreover, the number of Eimeria oocysts excreted in the group less than 1-year-old group was higher than older ( $>1$-year-old) animals investigated. These findings are in agreement with previous observations (Alyousif et al., 1992; Wang et al., 2010). This has been attributed to lower resistance or less immunity to Eimeria species in young animals compared to the older animals (Gregory et al., 1980; Kanyari, 1988; Maingi and Munyua, 1994).

In the present study, the prevalence and OPG of Eimeria species in wet season (60.22\% and $173.15 \pm 27.56$ OPG respectively) were significantly higher than that in dry season (45.81\% and $134.60 \pm 24.00$ OPG respectively). Similarly, Bakunzi et al. (2010), El-Bahy et al. (2008) and Majaro and Dipeolu (1981) found higher Eimeria oocyst counts during the hot, rainy season than those during the cold, dry season. ElBahy et al. (2008) reported that Coccidia sp. are abundant during April to June and their incubation period is about 1-2 week, so new infection could be occurs in the same period as end of March till end of June. On the contrast, other researchers observed that the overall OPG counts of goats were significantly higher during the dry season than those during the wet season (Harper and Penzhorn, 1999; Soliman and Zalat, 2003).

In conclusion, the prevalence of coccidiosis is relatively low compared to other studies. Moreover, no signs of clinical coccidiosis were found in this study. We need further research to study the interaction between multiple-species infections in coccidiosis and parasite load in natural host-parasite systems. These results also provide relevant base-line data for assessing the effectiveness of future control strategies against coccidiosis in goats.

\section{ACKNOWLEDGMENTS}

Project support was provided, in part, by Al-Baha University, Al-Baha, Saudi Arabia (Grant No. 4/1433). The author would like to thank Dr. Amrou A. F. Afssa, manager of Al-Baha official abattoir, for his assistance during sampling and sample preparation.

\section{REFERENCES}

Alyousif, M.S., Kasim, A.A. and Al-Shawa, Y.R. (1992). Coccidia of the domestic goat (Capra hircus) in Saudi Arabia. International journal for parasitology, 22(6): 807-811.

Bakunzi, F.R., Thwane, S.N., Motsei, L.E. and Dzoma, B.M. (2010). Diversity and seasonal occurrence of Eimeria species in a mixed flock of communally reared sheep and goats in Mafikeng in the North West Province, South Africa. Journal of the South African Veterinary Association, 81(3):148-150.

Balicka-Ramisz, A. (1999). Studies on coccidiosis in goats in Poland. Veterinary Parasitology, 81(4): 347-349. 
Bush, A.O., Lafferty, K.D., Lotz, J.M. and Shostak, A.W. (1997). Parasitology meets ecology on its own terms: Margolis et al., revisited. The Journal of parasitology, 83: 575-583.

Cavalcante, A.C., Teixeira, M., Monteiro, J.P. and Lopes, C.W. (2012). Eimeria species in dairy goats in Brazil. Veterinary Parasitology, 183(3-4): 356-358.

Dhar, D.N., Sharma, R.L. and Bansal, G.C. (1982). Gastro-intestinal nematodes in sheep in Kashmir. Veterinary Parasitology, 11(2-3): 271-277.

El-Bahy, M.M., Omer, O.H. and Al-Sadrani, A.A. (2008). Temperature difference and parasite infection at Qassim region, Saudi Arabia. Research Journal of Parasitology, 3: 114-122.

Gregory, M.W., Joyner, L.P., Catchpole, J. and Norton, C.C. (1980). Ovine coccidiosis in England and Wales 1978-1979. The Veterinary Record, 106: 461-462.

Gül, A. (2007). The prevalence of Eimeria species in goats in iğdir. Turkish Journal of Veterinary and Animal Sciences, 31(6): 411-414.

Harper, C.K. and Penzhorn, B.L. (1999). Occurrence and diversity of coccidia in indigenous, Saanen and crossbred goats in South Africa. Veterinary Parasitology, 82(1):1-9.

Ibrahim, M.M., Al Ghamdi, M.A. and Al Gahmdi, M.S. (2008). Helminths community of veterinary importance of livestock in relation to some ecological and biological factors. Türkiye Parazitoloji Dergisi, 32(1): 42-47.

Kanyari, P.W.N. (1988). Experimental infections with coccidiosis and serum antibody quantitation in two breeds of goats. Veterinary Parasitology, 28: 11-18.

Levine, N.D. (1985). Veterinary Protozoology. Iowa State University Press, Ames, IA, pp. 150-202.

MAFF (Ministry of Agriculture, Fisheries and Food, UK) (1986). Manual of veterinary parasitological laboratory techniques. Reference book 418 . Her Majesty's Stationery Office, London.

Maingi, N. and Munyua, W.K. (1994). The prevalence and intensity of infection with Eimeria species in sheep in Nyandarua district of Kenya. Veterinary Research Communications, 18: 19-25.

Majaro, O.M. and Dipeolu, O.O. (1981). The seasonal incidence of Coccidia infections in trade cattle, sheep, and goats in Nigeria. The Veterinary Quarterly, 3(2): 85-90.

Norton, C.C. (1986). Coccidia of domestic goats, Capra hircus, with notes on Eimeria ovinoidalis and E. bakuensis (E. ovina) from sheep Ovis aries. Parasitology, 92: 279-289.

Pellérdy, L.P. (1974). Coccidia and Coccidiosis, 2nd ed. Paul Parey, Berlin, pp. 720 794, 959.

Soliman, M.F.M. and Zalat, S.M. (2003). Prevalence and intensity of Nematodirus sp. and Eimeria sp. infections in the domestic goats of St. Katherine's Protectorate (Sinai, Egypt): relations with some ecological and biological factors. Egyptian Journal of Biology, 5: 78-85.

Soulsby, E.J.L. (1986). Helminths, arthropods and protozoa of domesticated animals, 7th Ed. Bailliere, London, UK, pp. 599-625.

Wang, C.R., Xiao, J.Y., Chen, A.H., Chen, J., Wang, Y., Gao, J.F. and Zhu, X.Q. (2010). Prevalence of coccidial infection in sheep and goats in northeastern China. Veterinary Parasitology, 174: 213-217. 


\section{ARABIC SUMMARY}

نسبة انتثار الإصابة بأنواع الأيمريا في ماعز منطقة الباحة ، المملكة العربية السعودية قسم علم الحيوان ، كلية العلوم ، جامعة قناة البرويس ، جمهورية مصر العربية

يهدف هذا العمل إلى تعريف أنواع الأيمريا في الماعز وفحص العوامل المحتملة التي تؤثر في نسبة

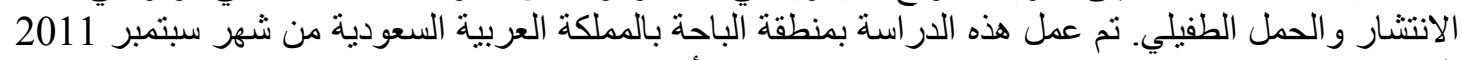

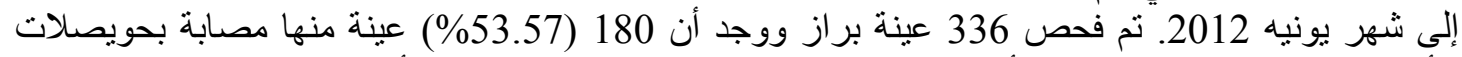

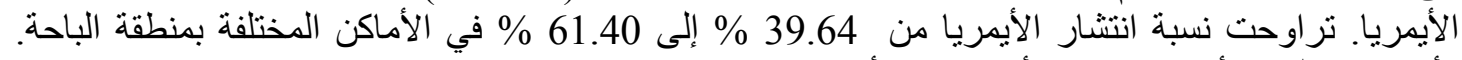


E. و E. caprovina ، E. jolchijevi ، E. caprina ، E. christenseni ، E. ninakohlyakimovae

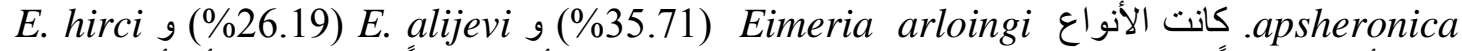

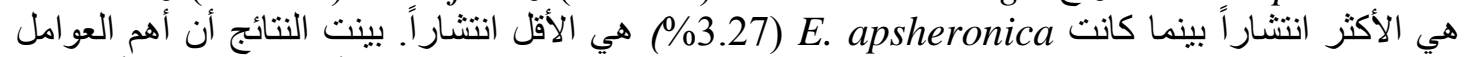

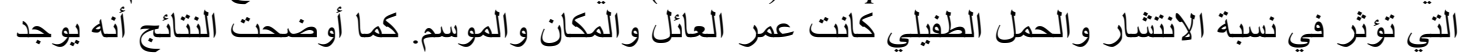

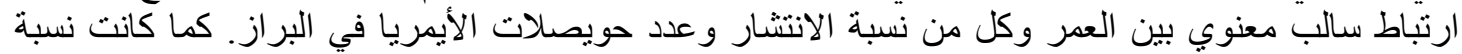

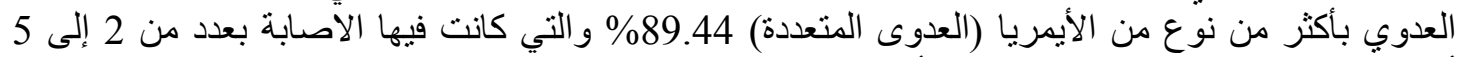

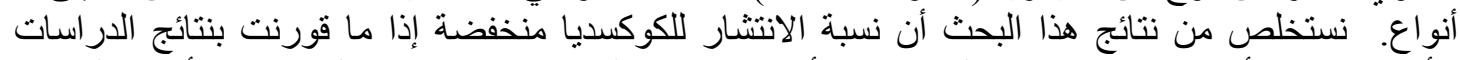



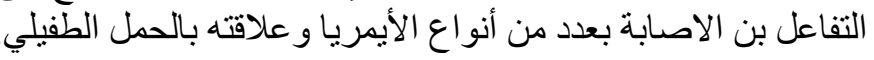

